\title{
Bessora, Sept secondes plus au nord, «La nouvelle revue française»
}

\section{Veronica Amadessi}

\section{(2) OpenEdition \\ 10 Journals}

\section{Édition électronique}

URL : http://journals.openedition.org/studifrancesi/7742

DOI : 10.4000/studifrancesi. 7742

ISSN : 2421-5856

Éditeur

Rosenberg \& Sellier

\section{Édition imprimée}

Date de publication : 1 décembre 2009

Pagination : 677

ISSN : 0039-2944

\section{Référence électronique}

Veronica Amadessi, « Bessora, Sept secondes plus au nord, «La nouvelle revue française» », Studi

Francesi [En ligne], 159 (LIII | III) | 2009, mis en ligne le 30 novembre 2015, consulté le 07 janvier 2021. URL : http://journals.openedition.org/studifrancesi/7742; DOI : https://doi.org/ERREUR PDO dans / localdata/www-bin/Core/Core/Db/Db.class.php L.34 : SQLSTATE[HY000] [2006] MySQL server has gone away

Ce document a été généré automatiquement le 7 janvier 2021.

\section{(c) $($ ) $(9)$}

Studi Francesi è distribuita con Licenza Creative Commons Attribuzione - Non commerciale - Non opere derivate 4.0 Internazionale. 


\title{
Bessora, Sept secondes plus au nord, «La nouvelle revue française»
}

\author{
Veronica Amadessi
}

\section{RÉFÉRENCE}

BESSORA, Sept secondes plus au nord, «La nouvelle revue française», octobre 2008, n. 587, pp. 36-49.

1 Bessora publie en avant-première dans la «Nouvelle Revue Française» sa dernière nouvelle. Ce texte, d'une dizaine de pages, surprend d'emblée le lecteur par l'exactitude des détails et la minutie de ses descriptions. Le personnage principal, un homme au caractère indécis et maniaque pour qui chaque geste devient un rituel, est présenté comme «un prototype». L'histoire se déroule à Paris, en l'espace d'une poignée de minutes nécessaires au "proto-héros» pour descendre chercher du pain et rentrer ensuite chez lui. Il s'agit d'un homme qui considère la vie comme un champ de Ba-taille, pour qui même l'accomplissement d'actions quotidiennes est une source d'angoisse. Les objets fétiches, la description du parcours et des personnes rencontrées ont un effet rassurant sur cet «homme-enfant» qui possède, dans sa maison, une fausse serre tropicale. Le personnage considère cette oasis comme son «Paradis perdu» et se réfugie dès qu'il peut dans ce monde parallèle, peuplé de plantes et d'animaux vrais et faux, d'êtres qui participent à sa folie et qui font partie de ses névroses. Il n'est pas donné au lecteur de connaître la réaction du personnage lorsque, rentré chez lui, il découvre que sa femme a tué ses animaux pour le repas du soir, mais il est certain que ce récit mettant en scène un couple en crise et sa folie est très percutant. D'abord, parce que le style et les choix d'écriture sont un miroir de la folie des deux personnages: le discours indirect libre est en effet au centre de la narration, ainsi que le dédoublement du point de vue. Ensuite, parce que Bessora brosse un tableau de personnages hauts en couleur, avec leurs tics et leurs tocs, oscillant, comme c'est souvent le cas dans ses romans, entre humour et sens du tragique. Sous l'effet comique de ces personnages, qui sont presque des caricatures, nous pouvons lire en effet le drame qui se consomme en filigrane; ce 
qui est certain, c'est que nous retrouvons ici le style et la verve d'une grande écrivaine francophone. 